\title{
Effects of tomato juices (Lycopersicum esculentum Mill) consumption on plasma lycopene levels of male light smokers
}

\author{
Ida Gunawan*, Sri Sukmaniah Sudardjat*, Septelia Inawati Wanandi ${ }^{f}$
}

\begin{abstract}
Abstrak
Penelitian ini merupakan penelitian eksperimental dengan desain pre dan post test, untuk mengetahui pengaruh konsumsi jus tomat (Lycopersicum esculentum Mill) terhadap kadar likopen plasma. Sampel darah dari 27 orang subyek penelitian dengan rata-rata usia 34,70 \pm 5,74 tahun, mempunyai tingkat pendidikan menengah (85,2\%), mengalami paparan langsung terhadap debu panas dalam pekerjaannya (40,74\%) dan merokok jenis rokok kretek (77,78\%), diberi perlakuan dengan jus tomat (Lycopersicum esculentum Mill) yang telah diolah sebanyak 350 gram/hari selama 4 hari berturut-turut. Kadar likopen plasma diperiksa sebelum dan sesudah perlakuan. Hasil penelitian menunjukkan bahwa kadar likopen plasma setelah perlakuan mengalami peningkatan yang secara statistik bermakna. Hal ini membuktikan bahwa konsumsi jus tomat yang diolah dengan benar ternyata mampu meningkatkan kadar likopen plasma. (Med J Indones 2004; 13: 146-50)
\end{abstract}

\begin{abstract}
The study was an experimental study with pre and post test design, to evaluate the effects of tomato juices (Lycopersicum esculentum Mill) consumption on plasma lycopene level. Blood sample of 27 subjects with average age of $34.70 \pm 5.74$ years old, moderate education level (85.2\%), experienced direct contact with working environmental pollutant (40.74\%) and smoked kretek cigarettes (77.78\%) were given treatment with 350 gram/day of tomato juices (Lycopersicum esculentum Mill) which had been properly prepared for 4 consecutive days. The lycopene plasma level was examined before and after treatment. The findings showed that after treatment, the lycopene plasma level significantly increased. This showed that consumption of properly prepared of tomato juices will increase the lycopene plasma level. (Med J Indones 2004; 13: 146-50)
\end{abstract}

Keywords: light smoker, tomato juices, lycopene plasma

There is an increasing evidence that diet can play an important role in human health by providing important substances that increase the body defense system against several diseases. Recent studies suggest that consumption of tomatoes products which are rich in lycopene, an antioxidant, can decrease the risk of the development of disease related to oxidative stress. $^{1}$

Analysis of carotenoids profile in tomato (Lycopersicum esculentum Mill) as: lycopene (60-64\%), phytoene (10-12\%), $\gamma$-carotene $(10-11 \%)$, neurosporene $(7-9 \%)$, phytofluene $(4-5 \%), \beta$-carotene $(1-2 \%), \delta$-carotene

\footnotetext{
* Department of Clinical Nutrition, Faculty of Medicine, University of Indonesia, Jakarta, Indonesia

${ }^{f}$ Department of Biochemistry, Faculty of Medicine,University of Indonesia, Jakarta, Indonesia
}

(1-2\%) and lutein (trace-1\%). It has been showed that high intake of some carotenoids (such as $\beta$-carotene, lutein, etc) may influence or antagonize the bioavailability and absorption of lycopene, although some researcher thought that this process remain a theoretical possibility, definitive data remain to be generated. ${ }^{2}$

Lycopene is reddish pigments, which can be found in fruits and vegetables (for examples tomato, watermelon, red grape, etc) including major carotenoids, without pro-vitamin A activity and fat soluble. It has been proved that lycopene has antioxidant activity by quenching singlet oxygen 2 times $\beta$ carotene and 10 times $\alpha$ tocoferol. ${ }^{3,4}$

The bioavailability of lycopene is reported to be highly variable and can be affected by a number of dietary factors, food properties, biologic and life style 
factors. These factors include amount of lycopene consumed in a meal, food matrix in which lycopene is incorporated, co ingestion of high amounts of dietary fiber, co-ingestion of fat as a delivery medium, interaction of lycopene with other carotenoids, aging and smoking habits. ${ }^{2,3}$

Cigarettes contains 4000 organic materials which are categorized as free radical ${ }^{5,6}$ and can cause oxidative damage to cells, for example per-oxidation of lipid membrane, damage of protein and deoxyribonucleic acid (DNA). The continuation oxidative damage is a significant contributor to the development of degenerative diseases. ${ }^{7,8}$ An adequate intake of lycopene is suggested to be one factor that protects the body from oxidative damage, such as smoking.

According to the Indonesian Household Health survey in 2002, the number of smokers have increased from $51.2 \%$ to $54.5 \%$ as compare to 1995 's survey. ${ }^{9,10}$ However, data on plasma lycopene level of Indonesian smokers are remained to be explored. Hence, our interest to study the effect of tomato juices (Lycopersicum esculentum Mill) consumption on plasma lycopene level of Indonesian male light smokers.

\section{METHODS}

An experimental study with pre and post test design was applied on 28 healthy male light smoker subjects $\left(\mathrm{n}=28,1\right.$ dropped out because of diarrhea), ${ }^{11}$ characterized as 20 - 55 years old, not taking any medication or vitamin supplements. Informed written consent was obtained from each participant and the protocol was approved by the ethics committee of the Medicine Faculty of the University Indonesia.

The data was collected from December to May 2003 at one of Multinational Company located in West Java. The study was done in 3 periods: (1) Preintervention period, to obtain baseline data of demographic characteristic, food intake and lycopene plasma level. (2) Intervention period, tomato juices consumption 350 gram/day was given to each subject and food intake data were collected for 4 consecutive days. (3) Post intervention period, to obtain laboratory data for plasma lycopene level.

Food intake data were collected by 2 x 24 hours recall method. Tomato juices were produced by steaming 350 gram fresh tomatoes for 10 minutes, juiced for 2.5 minutes and sift. The sifted volume was around 330 $\mathrm{mL}$ then mixed with coco pandan syrup about $20 \mathrm{~mL}$, which make the final volume about $350 \mathrm{~mL}$.

Lycopene plasma level was analyzed with HPLC based on SEAMEO laboratory method. Forty $\mu \mathrm{L}$ plasma was mixed with $100 \mu \mathrm{L}$ solution (ethanol : butanol $=50: 50$ ) for 1 minute. The mixture was centrifuged for 3 minutes at $1200 \mathrm{x}$ g. Twenty $\mu \mathrm{L}$ supernatan was analyzed for lycopene level with HPLC, which performed by using a RP18 column (Waters, Novapack) fitted with a guard column. The eluent consisted of acetonitril : tetrahidrofuran : methanol : $1 \%$ ammonium $(342 \mathrm{~mL}: 110 \mathrm{~mL}: 34 \mathrm{~mL}$ : $14 \mathrm{~mL}$ ) at a flow rate of $0.9 \mathrm{~mL} /$ minute and signal length was set at $450 \mathrm{~nm}$.

\section{RESULTS}

The average age of the subjects was $34.70 \pm 5.74$ years old, $85.2 \%$ had moderate education level with monthly income below the poverty line, $40.74 \%$ had direct contact with the working environmental pollutant and $77.78 \%$ smoked kretek cigarettes.

Nutrition intake (energy, fat, fiber, lycopene and $\beta$ carotene) after the intervention significantly increased $(p<0.05)$, except for $\beta$ carotene was not significantly increased (Table 1). As compare to the recommended intake in Table 2, only lycopene intake after the intervention and fat before and after intervention, were above the recommendation.

Based on SPSS (Statistical Product and Service Solutions) method, lycopene plasma level after intervention significantly increased $(p<0.0001)$ (figure 1). 
Table 1. Intake of energy, fat, fibre, lycopene, $\beta$ carotene before and after intervention

\begin{tabular}{lccccc}
\hline Variable & $\begin{array}{c}\text { Before } \\
(\mathrm{n}=27)\end{array}$ & $\begin{array}{c}\text { After } \\
(\mathrm{n}=27)\end{array}$ & $\mathrm{p}$ & Test & Significance \\
\hline Energy (kcal) & $1752.05 \pm 260.41$ & $1858.26 \pm 230.68$ & 0.040 & $\mathrm{t}$ & $\mathrm{S}$ \\
Fat $(\mathrm{g})$ & $61.40 *(33.95-108.20)$ & $74.33 *(45.30-102.90)$ & 0.012 & $\mathrm{~W}$ & $\mathrm{~S}$ \\
Fiber $(\mathrm{g})$ & $9.50 *(5.75-18.80)$ & $12.13 \pm 2.31$ & 0.009 & $\mathrm{~W}$ & $\mathrm{~S}$ \\
Lycopene $(\mathrm{mg})$ & $0.74 *(0.10-2.41)$ & $11.85 \pm 0.96$ & 0.0001 & $\mathrm{~W}$ & $\mathrm{~S}$ \\
$\beta$ carotene $(\mathrm{mg})$ & $0.10 *(0.05-0.75)$ & $0.13 *(0.05-3.88)$ & 0.105 & $\mathrm{~W}$ & $\mathrm{NS}$ \\
& & & & & \\
\hline
\end{tabular}

Note: data is presented by mean \pm standard deviation

* = median value (minimum - maximum)

$\mathrm{t} \quad=$ pair $\mathrm{t}$ test

$\mathrm{W}=$ Wilcoxon test

$\mathrm{S}=$ significance $(\mathrm{p}<0.05)$

NS $=$ non significance $(\mathrm{p}>0.05)$

Table 2. The intake percentages of fat, fibre, lycopene, and $\beta$ carotene compare to the recommendation by $2 \times 24$ hours recall method

\begin{tabular}{lccc}
\hline Variable & $\begin{array}{c}\text { Before } \\
(\mathrm{n}=27)\end{array}$ & $\begin{array}{l}\text { During } \\
(\mathrm{n}=27)\end{array}$ & Recommendation \\
\hline Fat $(\%)$ & 31,54 & 35,99 & $20-30^{\mathrm{a}}$ \\
Fibre $(\mathrm{g})$ & $9,5^{*}(5,75-18,80)$ & $12,13 \pm 2,31$ & $20-30^{\mathrm{a}}$ \\
Lycopene $(\mathrm{mg})$ & $0,74 *(0,10-2,41)$ & $11,85 \pm 0,96$ & $2,3^{\mathrm{b}}$ \\
$\beta$ Carotene $(\mathrm{mg})$ & $0,10 *(0,05-0,75)$ & $0,13 *(0,05-3,88)$ & $2,9^{\mathrm{b}}$ \\
\hline
\end{tabular}

Note: $\mathrm{a}=$ data from Konsensus Nasional Pengelolaan Dislipidemia di Indonesia (KNPDI), 1996

$\mathrm{b}=$ data from National Health Interview Survey ( NHIS ) 1992

$*$ = median value (minimum - maximum)

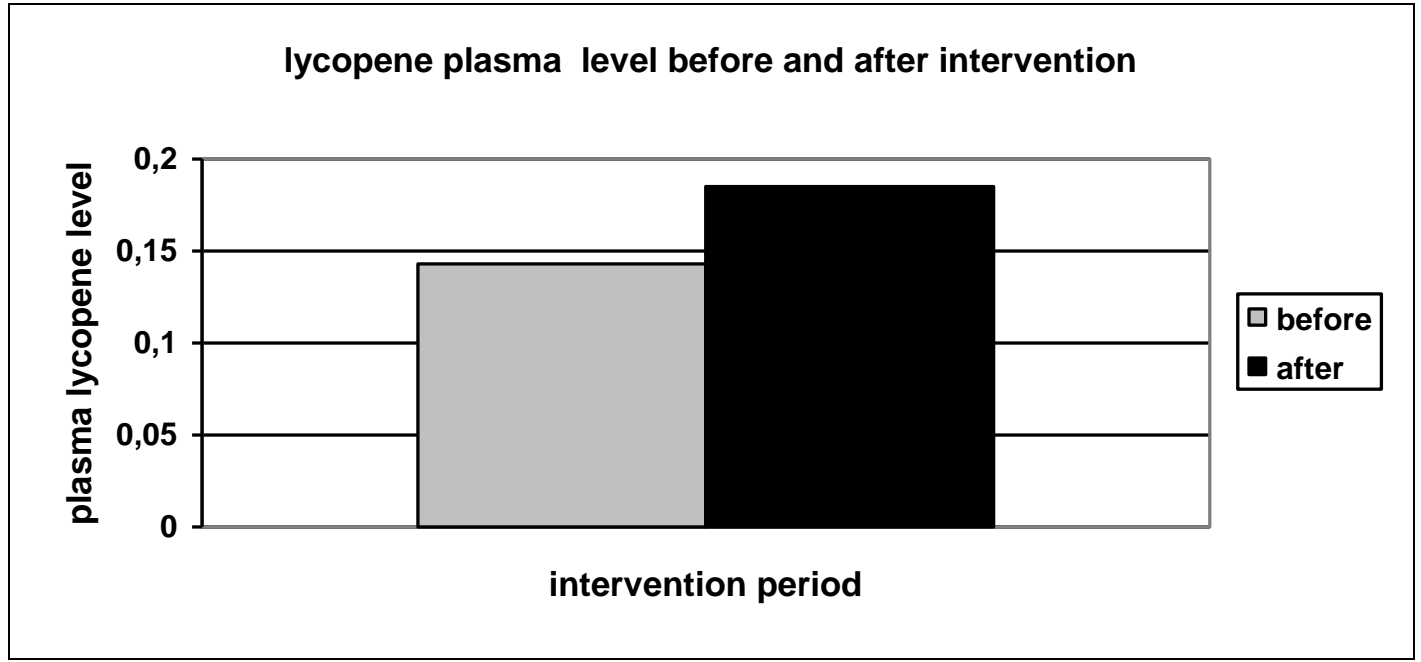

Figure 1. Plasma lycopene level before and after intervention 


\section{DISCUSSION}

Smoking tobacco correlates directly or indirectly with degenerative disease such as cancer, cardiovascular disease, etc. The increased risk of smoking tobacco might be due to oxidative damage of cellular components such as protein, lipid and DNA. Smoke of cigarettes contain of higher load of free radicals and other reactive oxygen species such as nitrogen oxides, carbon mono-oxide, tar, phenol, etc. Consequently the oxidant/antioxidant balance of smokers become perturbed, leading to oxidative stress.

In this study, most of the subjects $(82.52 \%)$ had moderate education level and monthly income below the poverty line. The level of education and monthly income had impact on the eating habit. ${ }^{12,13}$ By the moderate education level, it was expected that subjects had sufficient knowledge in choosing good quality of antioxidant food, but with a price matches their monthly income.

There were $40.74 \%$ subjects exposed directly to chemical pollutants especially hot dusts (with active lead) in their working environment. Lead $(\mathrm{Pb})$ can cause oxidative damages through free radical formation, which cause the decrease of body's antioxidant level. ${ }^{14,15}$

In addition, $77.78 \%$ subjects smoke kretek cigarettes which contain higher tar and nicotine level compare to mild/light cigarettes. Hence the oxidative damage is increased. ${ }^{15,16,17}$

According to Shi and Maguer study, it was proved that 100 gram tomatoes contain 3-5 mg lycopene. ${ }^{4}$ Porrini et al (1998) ${ }^{18}$ has been demonstrated that plasma lycopene level has achieved a steady state in the $4^{\text {th }}-7^{\text {th }}$ day of $16,5 \mathrm{mg} /$ day lycopene treatment. In order to achieve a higher level of lycopene, the tomato juices are properly prepared as described by Van Het Hoff et al (2000). ${ }^{19}$

The bioavailability of lycopene can be influenced by fat, fiber and $\beta$ carotene intake. Fat intake during intervention was higher than before intervention, which was $61.40(33.95-108.20)$ gram vs 74.33 (45.30 - 102.90) gram. The higher fat intake can support lthe bioavailability of ycopene. The fiber intake during intervention was higher than before the intervention, which was $9.50(5.75-18.80)$ gram vs $(12.13 \pm 2.31)$ gram. Fiber intake can reduce lycopene bioavailability as it increased the viscosity condition. Intake of $\beta$ carotene before and during the intervention i.e $0.10(0.05-0.75) \mathrm{mg}$ and $0.13(0.05-$ 3.88) $\mathrm{mg}$ was considered lower as compare to NHIS 1992's data, which is $2.9 \mathrm{mg}$. This occurred because of the competitive characteristics when it mixed with fat and micelle in intestine; in enterocyte during the intra-cellular transport; during transport by plasma lipoprotein and released \& retrieved of tissue. ${ }^{20}$ However the competitive characteristics will occur only when the subject has high dosage of $\beta$ carotene supplement, it was stated that by $300 \mathrm{mg} /$ day of $\beta$ carotene supplement for 21 days, will reduce lycopene serum level significantly. ${ }^{21,22}$ However in this study we assumed that the lower of $\beta$ carotene intake will not influenced the bioavailability of lycopene. This assumption was explained in the Australian polyp prevention project that used supplementation of $\beta$ carotene $(20 \mathrm{mg} /$ day) for 2 years, which increase the plasma lycopene concentration of approximately $175 \%$ was compared with placebo. ${ }^{2}$

The lycopene intake during the intervention was higher than before the intervention, which was 0.74 $(0.10-2.41) \mathrm{mg}$ vs $(11.85 \pm 0.96) \mathrm{mg}$. This was related to the consumption of tomato juices of 350 $\mathrm{mL}$, made from a 350 gram tomatoes (estimated around 100 gram tomatoes contain $3-5 \mathrm{mg}$ lycopene). ${ }^{23}$ Although most subject have moderate education level, the lycopene intake before the intervention was considered lower than NHIS 1992's data, ${ }^{17}$ which was $0.74 \mathrm{mg}$ vs $2.3 \mathrm{mg}$. This findings showed that the food source of lycopene, especially tomato is not the day-to-day food consumed by Indonesian, like the westerners.

After determination with HPLC method for plasma lycopene level, the median value of plasma lycopene level before and after intervention showed a significant increase $(39.1 \% ; \mathrm{p}<0.0001)$, although lycopene intake before intervention of $0.74 \mathrm{mg}$ was less than NHIS 1992 data which is $2.3 \mathrm{mg}$. It may be due to the higher bioavailability of lycopene caused by the higher fat intake. The plasma lycopene level of the subjects before intervention $(0.143 \mu \mathrm{mol} / \mathrm{L})$ was considered normal $(0.05-1.05 \mu \mathrm{mol} / \mathrm{L}){ }^{25}$

In this study showed that the bio-availability of lycopene is very much influenced by nutritional factors especially fat other than biology factors such as age, sex, alcohol and smoking. 


\section{CONCLUSION}

Tomato juices consumption in properly dose and prepared can increased the plasma lycopene level. Further study are required to observe the effect of increasing plasma lycopene level on the repair of oxidative damage as well as the prevention of degenerative diseases, especially in smoker subject.

\section{REFERENCES}

1. Porrini M, Riso P. Lymphocyte lycopene concentration and DNA protection from oxidative damage is increased in women after a short period of tomato consumption. $\mathrm{J}$ Nutr 2000; 130:189- 92.

2. Clinton SK. Lycopene : Chemistry, biology, and implications for human health and disease. Nutr Rev 1998; 56:35-51.

3. Agarwal S, Rao AV. Tomato lycopene and its role in human health and chronic diseases. Can Med Assoc J 2000;163:739-44.

4. Shi J, Maguer ML. Lycopene in tomatoes : Chemical and physical properties affected by food processing. Crit Rev Biotechnol 2000;20:293-334.

5. Aditama TY. Penyakit akibat rokok, dalam Masalah Merokok dan Penanggulangannya. (Patarai A.A.P., editor) edisi ke 1, hal. $1-7$. Yayasan Penerbit Ikatan Dokter Indonesia (YP-IDI) bekerjasama dengan Perhimpunan Dokter Paru Indonesia (PDPI) dan Lembaga Menanggulangi Masalah Merokok (LM-3), Jakarta, 2001

6. Lim PS, Wang NP, Lu TC, Wang TH, Hsu WH, Chan EC, Hung WR, Yang CC, Kuo IF, Wei YH. Evidence for alterations in circulating low-molecular-weight antioxidants and increased lipid peroxidation in smokers on hemodialysis. Nephron 2001; 88:127-33.

7. Fahn HJ, Wang LS, Kao SH, Chang SC, Huang MH, Wei YH. Smoking-associated mitochondrial DNA mutations and lipid peroxidation in human lung tissues. Am J Respir Cell Mol Biol 1998;19:901-9.

8. Sirait AM, Pradono J, Toruan IL. Pola kebiasaan merokok pada penduduk Indonesia, dalam Survei Kesehatan Rumah Tangga 2002:291-6.

9. Madiyono B, Moeslichan Mz S, Sastroasmoro S, Budiman I, Purwanto SH. Perkiraan besar sampel. Dalam: Sastroasmoro S, Ismael S, editors. Dasar-Dasar Metodologi Penelitian Klinis. Edisi ke-1. Jakarta: Binarupa Aksara, 1995:187-212.

10. BPS http :

//www.bps.go.id/statbysector/notreg/gdp/table 7.shtml (akses 12/9/2002).
11. Soekirman JF. Perkembangan pemanfaatan data antropometri. Dalam: Gizi menuju peningkatan kualitas sumber daya manusia. Kongres VIII Persatuan Ahli Gizi Indonesia. Jakarta 1990:91-6.

12. Chu RP. Free radicals and antioxidants in atherosclerosis. Dalam: Tjokroprawiro A, Pranawa, Adi S, editors. Simposium "Oksidan dan Antioksidan" Peranannya Dalam Mencegah Progresivitas Kelainan Pembuluh Darah Persatuan Ahli Penyakit Dalam Indonesia, Surabaya, 1993; 61-73.

13. Hoffmann D, Hoffmann I. The changing cigarette. J Toxicol Environ Health 1997;50:307-64.

14. Halliwell B, Gutteridge JMC. Free Radicals in Biology and Medicine. Edisi ke-3. Oxford University Press, London, 1999:220-5; 388-90.

15. Aditama TY. Senjata baru untuk melawan rokok. Kompas 2003: 31 Mei, hal. 10.

16. Holden JM, Eldridge AL, Beecher GR, Buzzard IM, Bhagwat S, Davis CS, Douglass LW, Gebhardt S, Haytowitz D, Schakel S. Carotenoid content of U.S. foods: an update of the database. J Food Composition Analysis 1999; 12:169-96.

17. DRI. $\beta$-Carotene and other carotenoids, dalam Dietary Reference Intakes for Vitamin C, Vitamin E, Selenium, and Carotenoids, National Academy Press, Washington DC, 2000:325-72.

18. Porrini M, Riso P, Testolin G. Absorption of lycopene from single or daily portions of raw and processed tomato. Br J Nutr 1998;80:353-61.

19. Van Het Hof KH, De Boer BCJ, Tijburg LBM, Lucius BRHM, Zijp I, West CE, Hautvast JGAJ, Weststrate JA. Carotenoid bioavailability in humans from tomatoes processed in different ways determined from the carotenoid response in the triglyceride-rich lipoprotein fraction of plasma after a single consumption and in plasma after four days of consumption. J Nutr 2000; 130: 1189-96.

20. Brady WE, Mares-Perlman JA, Bowen P, StacewiczSapuntzakis M. Human serum carotenoid concentrations are related to physiologic and lifestyle factors. J Nutr 1996;126:129-37.

21. Wei W, Kim Y, Boudreau N. Smoking and antioxidant serum levels. Am J Public Health 2001; 91:258-64.

22. Van den Berg H. Carotenoid interaction. Nutr Rev 1999;57:1-10.

23. Lee A, Thurnham DI, Chopra M. Consumption of tomato products with olive oil but not sunflower oil increases the antioxidant activity of plasma. Free Radic Biol Med 2000; 29:1051-5.

24. Marangon K, Herbeth B, Lecomte E, Paul-Dauphin A, Grolier P, Chancerelle Y, Artur Y, Siest G. Diet, antioxidant status, and smoking habits in French men. Am J Clin Nutr 1998;67:231-9.

25. Deming DM, Erdman JW. Mammalian carotenoid absorption and metabolism. Pure Appl Chem 1999; $71: 2213-23$. 